\title{
Relationship of Knowledge, Attitude with SADARI Behavior as an Early Detection of Breast Cancer in Students of The Faculty of Public Health
}

\author{
${ }^{1}$ Arfah Husna, ${ }^{1}$ Siti Maisyaroh Fitri Siregar, ${ }^{1}$ Azwar \\ ${ }^{1}$ Faculty of Public Health, Universitas Teuku Umar, Indonesia \\ Coresponding author:Arfah Husna, email: arfahhusna@utu.ac.id \\ Co-author: SMFS: sitimaisyaroh@utu.ac.id, A: azwar@utu.ac.id \\ Submitted:25/10/2021 Revised:05/04/2021 Accepted:09/04/2021 Published online:14/04/2021
}

doi: https://doi.org/10.35308/j-kesmas.v7i2.1646. How to cite this article: Husna, A., Siregar, S.M.A \& Azwar (2021).

Relationship of Knowledge, Attitude with Sadari Behavior as an Early Detection of Breast Cancer in Students of The

Faculty of Public Health. J-Kesmas: Jurnal Fakultas Kesehatan Masyarakat (The Indonesian Journal of Public Health).

8(1): $21-24$

\begin{abstract}
Breast cancer cases are quite high in Indonesia, namely 42 per 100.000 population and are the main cause of death for women in Indonesia. The purpose of this study was to analyze the relationship between knowledge and attitudes with awareness behavior (self-breast examination) in students of the Faculty of Public Health, Teuku Umar University, Meulaboh. The research design was cross sectional with a quantitative approach with univariate and bivariate analysis. The population of this study were female students at the Faculty of Public Health, Teuku Umar University Meulaboh, West Aceh Regency with a sample of 143 female students. The results of the study concluded that most of the respondents had never realized it as many as 84 people (58.7\%). The factors of knowledge and attitudes about awareness are related to the behavior of being aware
\end{abstract}

Keywords: Knowledge; Attitude; Behaviour; Breast cancer

\section{Introduction}

Data from the World Health Organization (WHO) in the Indonesian Ministry of Health (2015) that cancer is the second leading cause of death in the world at $13 \%$ after cardiovascular disease. Breast cancer cases occurred in women aged 50 years and over $(78 \%)$, while in women aged 40 years $(6 \%)$. However, many women who are 30 years old suffer from this deadly disease. This disease generally occurs in women, but can also occur in men.

According to GLOBOCAN (IARC) in 2012, it was found that $43.3 \%$ of cancer cases were breast cancer cases and $12.9 \%$ of deaths were due to breast cancer. GLOBOCAN data show that breast cancer has a lower mortality rate than the percentage of new cases, so that if breast cancer can be detected and treated early, the chances of cure will be higher. The problem in implementing BSE as an early detection method for breast cancer is that it is rarely done correctly. Only $25 \%$ to $30 \%$ do BSE properly and regularly every month (Kemenkes RI, 2012).

Previous research studies conducted by researchers on January 14, 2019 at FKM UTU Meulaboh, with the interview method on BSE to 15 students of the UTU FKM, and only 5 (five) people who answered correctly. This study aims to analyze the relationship between knowledge and attitudes about awareness with conscious behavior in the early detection of breast cancer among Meulaboh students.

\section{Methods}

The method used quantitative analytic with crosssectional approach. The sample of this research was 143 students of FKM UTU. The data analysis of this research is univariate and bivariate analysis. The tool used for data collection in this study was a questionnaire.

\section{Results}

The results of the univariate analysis of age factors, family history of suffering from cancer, history of respondents suffering from cancer, knowledge, attitudes about awareness and conscious action can be seen in the tables below:

Table 1. Distribution of factor scores age, knowledge, attitudes about awareness student

\begin{tabular}{lll}
\hline Variable & Mean & Median \\
\hline Age & 19.40 & 19 \\
Knowledge & 7.66 & 8 \\
Attitude & 33.06 & 33 \\
\hline
\end{tabular}

(Source, primer data, 2020)

Based on the results of the analysis in table 1, it is known that the average age of female students is 19.4 
years, the average knowledge of female students is 7.66 and the average score of female attitudes is 33.06.

Table 2. Distribution according to the Behavior SADARI of UTU FKM Students

\begin{tabular}{lll}
\hline $\begin{array}{l}\text { SADARI } \\
\text { Behavior }\end{array}$ & Frekuensi & Persentase \\
\hline Ever & 84 & 58.7 \\
Never & 59 & 41.3 \\
\hline Total & 143 & 100 \\
\hline
\end{tabular}

(Source, primer data, 2020)

Based on this research, it is known that most of the respondents never realized, namely as many as 84 people $(58.7 \%)$

Table 3. Distribution of female

\begin{tabular}{lcc}
\hline Variable & F & Percentage \% \\
\hline Family History of Cancer Breast & \\
No & 137 & 95.2 \\
Yes & 6 & 4.8 \\
Respondent's & History of & Suffering cancer \\
No & 140 & 97.9 \\
Yes & 3 & 2.1 \\
Knowledge & & \\
Less & 71 & 49.7 \\
Good & 72 & 50.3 \\
Attitude & & \\
Less & 65 & 45.5 \\
Good & 78 & 55.5 \\
\hline
\end{tabular}

(Source, primer data, 2020)

From table 3 it is known that a greater proportion (95.8\%) of female students had no family history of suffering from breast cancer, namely $95.8 \%$ and most respondents had no history of suffering from cancer, as much as $\mathbf{9 7 . 8 \%}$. Meanwhile, respondents with good and less knowledge levels were relatively the same, respectively $72(50.3 \%)$ and $71(49.7 \%)$, and female students with good attitudes were 78 people $(54.5 \%)$.

\section{Bivariate Analysis}

Bivariate analysis was conducted to determine several variables that may be related to awareness behavior in female students, between the independent variable and the dependent variable

\section{Discussion}

\section{SADARI Behavior}

The appearance of a lump in the breast can actually be detected quickly by self-examination. BSE is a way to check your own breasts. Self-examination is recommended to be carried out regularly, namely once a month. The results showed that out of 143 students, West Aceh Regency, 59 people (41.3\%) had ever realized it, and more than half of the students who never did Sadari were 84 people $(58.7 \%)$. This research is in line with the results of research conducted by Wulandari, F \& Ayu, S, M (2017) on 170 PGSD Students of STIKIP Muhammadiyah Kuningan, West Java Province, research by Anggraini, R (2017) on adolescent girls, research by Sinaga, C, F \& Ardayani, T (2016) on teenage girls at SMA 18 Pasundan, research on Tambunan, R (2017).

\section{Relationship Between Respondents Knowledge with Behavior SADARI as early Detection of Breast Cancer}

Based on the results of the study, it is known that there is a relationship between female students knowledge SADARI with SADARI behavior of students. This research is in line with research conducted by Handayani (2008), namely the relationship between the level of knowledge and the behavior of the respondent in performing breast selfexamination in Kalangan Village, Pedan Klaten District, Central Java. and research by Adelia, S, (2017) that there is a significant relationship between the level of knowledge and the awareness behavior of the student at STIKES Nani Hasanuddin Makasar.

The results of this study are also in line with Murnita and Parlindungan, F (2014) research on female adolescents in Grade 1 of SMAN Manggeng, Research by Lakshmi M, S \& Sugunnadevi G (2017) on women aged 20-30 years, Research Sheetal K, et al., (2019) on among females of urban slums of or above 35 years of age, Research Katkuri, S \& Gorantla, M (2019), at women age 15 years and above in urban slums, This research is also in line with research conducted by Desanti, O, I et al., (2010) in the city of Semarang, Central Java, research by Reynaldi, F et al., (2020) in household waste in Johan Pahlawan district, Aceh Barat. The research by Poppy, C, P \& Farismi, T, N (2015) at the Sibigo Public Health Center, West Simeulue District, Simeulue Regency, research by husna, A \& Fahlevi, M, I (2020) in young women at High school West aceh regency.

\section{Relationship between Respondents' Attitudes with Behavior SADARI as Early Detection of Breast Cancer.}

The results of research at FKM UTU show that 
attitudes have a relationship with conscious behavior, with a $\mathrm{p}$ value of 0.013 and an OR value $(95 \% \mathrm{CI})$ of 2.355 , meaning that respondents who have good attitudes have a chance to implement Sadari twice compared to respondents who have less attitudes. This result is in line with the research conducted by Rianti, at UPN "Veteran" Jakarta Faculty of Medicine students, research by Susi Adelia et al., (2017) that there is a significant relationship between the level of knowledge and the conscious behavior of the student at STIKES Nani Hasanuddin Makasar, Sherin Ishaaque et al., (2019). Respondents have a good attitude about BSE but BSE knowledge and practice is very poor, Sinaga, S, F \& Handayani, the research has a relationship between knowledge and attitudes of young women about breast cancer early detection through BSE at Pasundan Hight School. The study conducted by wahyuni, D. (2015) in housewives in Jati Village, the research by Briliana, A. (2017) to housewives in SidotopoWetan Kenjeran Village, Surabaya District

\section{Conclusion}

Respondents who had realized it were 59 people (41.3\%). The knowledge and attitude factors have a significant relationship with the Conscious Behavior of Students of the Meulaboh FKM UTU, West Aceh Regency.

For the FKM UTU Meulaboh, Aceh Besar District, to add KIA and Kespro subject matter to the public health curriculum on breast self-examination (realize) as early detection of breasts and increase awareness of continuous health education and also delivery of information through leaflets. Pocket books are needed by students of FKM UTU Meulaboh Aceh Besar District to increase knowledge and change attitudes so as to foster student interest and motivation for early detection of breast cancer by realizing it.

\section{Acknowledgement}

Thank you to the Dean of FKM UTU who allowed this research

\section{Author Contribution and Competing Interest}

Author contributions in this research are involved in the desaign of research projects, collecting data or analyzing results, involved in drafting or revising scientific papers

\section{References}

Angrainy, R (2017). Hubungan Pengetahuan, Sikap Tentang SADARI dalam mendeteksi dini kanker payudara pada remaja. Journal Endurance. 2(2). 232.

Adelia, S (2018). Hubungan Pengetahuan dan Sikap dengan SADARI dalam Upaya Deteksi Dini Kanker Payudara pada Mahasiswi DIII Farmasi Angkatan 2017 Stikes NANI Hasanuddin Makasar. Jurnal Ilmiah Kesehatan 12(5).

Bakhtayatchalam, A, (2019). Level of Knowledge regarding breast cancer and breast selfexamination among work women in Tamil Nadu. IJCMPH. 6(10).

Briliana, A, (2017). Faktor yang berhubungan dengan perilaku ibu rumah tangga melakukan pemeriksaan payudara sendiri (sadari). the indonesian journal public health. 12(2): 143153.

Depkes (2015). Situasi Penyakit Kanker. Pusat data dan Informasi Kementerian Kesehatan RI. Jakarta

Friska Wulandari, F \& Ayu, S, M. (2017). Hubungan Tingkat Pengetahuan dan Sikap Dengan Perilaku Pemeriksaan Payudara Sendiri (SADARI) Mahasiswi. Prosiding Seminar Nasional IKAKESMADA" Peranan Tenaga Keehatan dalam Pelaksanaan SDG": 137-144.

Reynaldi, F, (2020) The influence of knowledge and support of community leaders in the application of $3 \mathrm{R}$ (reduce, reuse, recycle) in household waste in Johan Pahlawan district, aceh barat district. Journal NX-A Multidisciplinary Peer Reviewed Journal. 6(6): 626-632.

Husna, A \& Fahlevi, M, I (2020). Implementation of SADARI in the Early Detection of Breast Cancer in Young Women High School of West Aceh Regency. J. Pub. Health, 7(1): 5156

Ishaaque, S, (2019). The practice of BSE attitudes and behaviors in rural areas in North Kerala. IJMPH. 6(5).

Kemenkes RI. (2012). Deteksi Dini Kanker Payudara. Kemenkes RI. Jakarta

Katkuri S \& Gorantla M (2019). Awerness about breast cancer among women aged 15 years anda above in urban slums: a cross sectional study. IJCMPH.

Lubis. U. L (2017).SADARI. Jurnal Kesehatan Panca Bhakti Lampung. 7(2). 109-116 
Murnita \& Parlindungan, F (2014). Hubungan Perilaku Remaja Putri Terhadap Pemeriksaan Payudara Sendiri (SADARI) di SMU Negeri 1 Kelas III Manggeng. J. Pub. Health, 2(2): 78-86

Poppy, C, P \& Farismi, T, N (2015). Hubungan Perilaku Masyarakat dengan Kejadian Penyakit Tidak Menular di Puskesmas Sibigo Kecamatan Simeulue Barat Kabupaten Simeulue. J. Pub. Health. 2(2): 40-53.

Ramli H. M. \& Umbas, U (2004). Pedoman, penemuan dan penatalaksanaan penyakit kanker tertentu di komunitas. Jakarta. Depkes.

Rianti (2011). Hubungan Pengetahuan dan Sikap tentang Sadari dengan Perilaku Sadari sebagai Deteksi Dini Kanker Payudara pada Mahsiswi Fakultas Kedokteran UPN "Veteran" Jakarta. Jurnal Kedokteran. 2(2): 31-36.

Sinaga, C, F \& Ardayani, T. (2016). Hubungan Pengetahuan dan Sikap Remaja Putri tentang Deteksi Dini Kanker Payudara melalui Periksa Payudara Sendiri di SMA PAsundan 8 Bandung.
Kartika. Jurnal Ilmiah Farmasi

Tambunan, R (2017). Hubungan Tingkat Pengetahuan tentang SADAR idengan Perilaku SADARI sebagai Deteksi DINI Kanker Payudara pada Mahasiswa DIII Kebidanan Kharisma Husada Binjai. 2(2): 117

Santana L.M \& Sugunadevi,G (2017). A Crosssectional study on knowledge about breast cancer among women aged 20-30 years. IJCMPH. 6(3).

Yusnilawati et al., (2019). Pendidikan Kesehatan tetntang Deteksi Dini Kanker Payudara melalui Pemeriksaan SADARI (Periksa Payduara Sendiri) di Pondok Pesantren Al Hidayahdan AL-Maarif Kota Jambi. Jurnal Karya Abdi Masyarakat, 3(2). 129-132

Wahyuni, D, et al., (2015). Hubungan Tingkat Pengetahuan dan Sikap terhadap Pelaksanaan SADARI pada Ibu Rumah Tangga di Kelurahan Jati. Andalas. Journal of Health. 4(1) from a scaled-up model in Indonesia. Health Policy and Planning, 12(1): 347-357 